\title{
Toxic haptophyte Prymnesium parvum affects grazing, survival, egestion and egg production of the calanoid copepods Eurytemora affinis and Acartia bifilosa
}

\author{
Sanna Sopanen ${ }^{1, *}$, Marja Koski ${ }^{2}$, Pirjo Kuuppo ${ }^{1}$, Pauliina Uronen ${ }^{1,3}$, \\ Catherine Legrand ${ }^{4}$, Timo Tamminen ${ }^{1}$ \\ ${ }^{1}$ Finnish Environment Institute (SYKE), PO Box 140, 00251 Helsinki, Finland \\ ${ }^{2}$ Danish Institute for Fisheries Research, Kavalergården 6, 2920 Charlottenlund, Denmark \\ ${ }^{3}$ Tvärminne Zoological Station, 10900 Hanko, Finland \\ ${ }^{4}$ Marine Sciences Department, University of Kalmar, 39182 Kalmar, Sweden
}

\begin{abstract}
Nitrogen- and phosphorus-depleted or NP-balanced toxic haptophyte Prymnesium parvum was fed to 2 dominant copepod species of the northern Baltic Sea (Eurytemora affinis and Acartia bifilosa), and their ingestion, egg and faecal pellet production rates and mortality were measured. The copepods were incubated in 5 different cell concentrations of $P$. parvum for 3 consecutive days; the cryptophyte Rhodomonas salina was used as a control for non-toxic, nutritionally high-quality food. Toxicity (haemolytic activity) of $P$. parvum was measured before and after the incubations. The haemolytic activity of $P$. parvum was the highest in cultures grown under nutrient deficiency. The toxicity decreased after $1 \mathrm{~d}$ incubation in all treatments, in both the presence and absence of copepods. Neither of the copepod species ingested P. parvum, irrespective of the nutrient treatment (toxicity) or cell concentration, and the pellet and egg production rates were correspondingly low. Although there was no significant increase in mortality in $P$. parvum treatments, copepods that were exposed to P. parvum in any concentration or nutrient treatment soon became inactive. It was evident that the toxicity of even nutrient-replete $P$. parvum had an indirect and sublethal influence on copepods, although this could not be measured as short-term increased mortality. Our results suggest a strong reduction in secondary production of copepods in an event of a P. parvum bloom.
\end{abstract}

KEY WORDS: Prymnesium parvum $\cdot$ Feeding $\cdot$ Toxicity $\cdot$ Food quality $\cdot$ Nutrient limitation $\cdot$ Acartia bifilosa $\cdot$ Eurytemora affinis $\cdot$ Copepods

Resale or republication not permitted without written consent of the publisher

\section{INTRODUCTION}

Blooms of toxic haptophytes are well-known nuisances in several areas around the world (Richardson 1997). Harmful blooms of Prymnesium parvum and Chrysochromulina polylepis have been reported from coastal brackish water ecosystems, e.g. in the Kattegat-Skagerrak area (Nielsen et al. 1990), in Norwegian fjord systems (Kaartvedt et al. 1991, Aure \& Rey 1992), in Australian estuaries (Hallegraeff 1992), and in fish ponds in China (Guo et al. 1996). Globally, these blooms are hazardous to coastal planktonic organisms and cause great economic loss to commercial aquaculture. Prymnesiophytes are common members of the summer phytoplankton community in the Baltic Sea, but so far only a few toxic-bloom incidents have been reported in Finnish coastal waters (Lindholm \& Virtanen 1992, Lindholm et al. 1999). P. parvum is a truly euryhaline species that usually blooms in fairly shallow eutrophic areas, where water exchange is limited (Edvardsen \& Paasche 1998).

The toxicity of Prymnesium parvum blooms is caused by actively excreted compounds (Shilo 1971) that are haemolytic, ichthyotoxic and cytotoxic (Shilo 
1971, Igarashi et al. 1998). Furthermore, several studies have shown that both nitrogen and phosphorus limitation enhance the toxicity of $P$. parvum (Shilo 1971, Johansson \& Granéli 1999, Uronen et al. 2005).

Interactions between toxic algae and zooplankton are complex. For example, some copepod species can ingest toxic phytoplankton cells without any immediate effect, while other species suffer high mortality after feeding on toxic algae (Turner \& Tester 1997). Ingestion of toxic algae may repress copepod egg production or hatching success (Uye 1996, Schmidt \& Jónasdóttir 1997, Dutz 1998, Koski et al. 1999b). Ingestion of toxic cells or exposure to toxic-cell exudates may also cause physiological stress with lethal or sublethal effects (Uye \& Takamatsu 1990, Carlsson et al. 1995). Rejection of toxic algae can lead to starvation if alternative food is scarce (Teegarden 1999, Guisande et al. 2002), or the ingestion of nutritionally highquality food can be perturbed in the presence of toxic algae, with the same result (Koski et al. 1999b). In addition, allelopathic effects of the toxins on other phytoplankton may reduce the availability of suitable food, which can affect resource competition within the grazer community (Fistarol et al. 2003, Granéli \& Johansson 2003).

Toxic effects of prymnesiophytes on zooplankton have been sparsely studied. Nejstgaard \& Solberg (1996) studied the effect of Prymnesium patelliferum (currently considered to be the same species as Prymnesium parvum; Larsen 1999) on the copepod Acartia clausi, and they found depressed feeding and egestion rates already at moderate algal concentrations, but no increase in mortality. In contrast, Koski et al. (1999b) showed that Eurytemora affinis was able to feed on $P$. patelliferum in single-species experiments and in algal mixtures. However, the positive feeding response resulted in increased mortality, abnormally low pellet production and suppressed fecundity of $E$. affinis. Furthermore, the presence of $P$. patelliferum in mixtures with nutritionally high-quality algal food decreased the copepod feeding rate on the high-quality alternative. Similar controversy exists in microzooplankton studies. For example, elevated mortality and low feeding of the ciliate Euplotes affinis on P. parvum has been demonstrated (Fistarol et al. 2003, Granéli \& Johansson 2003), but Barreiro et al. (2005) observed similar ingestion rate of the rotifer Brachionus plicatilis on $P$. parvum as on Rhodomonas salina, even though the mortality of $B$. plicatilis increased in the presence of P. parvum.

Because previous studies on the relationships between copepods and prymnesiophytes (Nejstgaard \& Solberg 1996, Koski et al. 1999b) are controversial, and because they have not taken into account the nutritional status of Prymnesium parvum, we present responses of 2 dominant copepod species in the Gulf of Finland (Baltic Sea), Eurytemora affinis and Acartia bifilosa, to toxic prymnesiophyte $P$. parvum or nontoxic cryptomonad Rhodomonas salina. In our experiments, we also tested whether the nutritional status of P. parvum (N-depleted, P-depleted or NP-balanced) modifies its toxicity and effects on copepods. Our main questions were: (1) Does the presence of toxic $P$. parvum have an effect on the survival and activity of $E$. affinis or Acartia bifilosa? And, if so, does it depend on the concentration or nutritional status of $P$. parvum? (2) What are the feeding responses (grazing and pelletproduction rate) of the 2 copepod species to the toxic $P$. parvum? (3) Does ingestion of $P$. parvum reduce the fecundity of the copepods?

\section{MATERIALS AND METHODS}

Cultures. The cryptomonad Rhodomonas salina (Rho; equivalent spherical diameter [ESD] ca. $7 \mu \mathrm{m}$ ) was used as a control of non-toxic food. It was obtained from the culture collection (TV 22/4) of the Tvärminne Zoological Station, University of Helsinki, Finland, and grown in batches in f/2 medium (Guillard \& Ryther 1962) at $15^{\circ} \mathrm{C}$ under a $14: 10 \mathrm{~h}$ light:dark cycle. The haptophyte Prymnesium parvum (Pry; ESD ca. 7 to $9 \mu \mathrm{m}$; strain KAC 39) was obtained from the Kalmar Algal Collection, University of Kalmar, Sweden. P. parvum was grown either under NP-balanced conditions (modified f/20 media, Guillard \& Ryther 1962) or under nitrogen $(-\mathrm{N})$ or phosphate $(-\mathrm{P})$ deficiency in semi-continuous cultures, where $20 \%$ of the culture was removed daily and the same amount of new media was added (Johansson \& Granéli 1999). Cultures were aerated gently, and the temperature was kept at ca. $+16^{\circ} \mathrm{C}$. Both species are oval/spherical flagellates commonly occurring in the Baltic Sea and of a suitable size range for the copepods used in the present study (e.g. Berggreen et al. 1988). Detailed description of culturing methods and $P$. parvum growth and toxicity are presented in Uronen et al. (2005).

Experiments. All experiments were conducted with adult females of Eurytemora affinis or Acartia bifilosa, which are the dominant copepods in the Gulf of Finland, Baltic Sea. The copepods were collected $1 \mathrm{~d}$ prior to the experiments using a $200 \mu \mathrm{m}$ plankton net on the SW coast of Finland, where salinity was around 6 psu and temperature ca. $15^{\circ} \mathrm{C}$ (for a description of the study area, see Niemi 1975). To collect E. affinis, portions of the net haul were gently narcotized with a few drops of 5\% MS-222 (tricaine methanesulfonate; Sigma-Aldrich) according to Dussart \& Defaye (2001) and adult females were collected using a stereo microscope. The copepods recovered quickly after they 
were transferred to $0.2 \mu \mathrm{m}$-filtered seawater. For $A$. bifilosa no narcotics were used. Before the experiments, the copepods were placed in $64 \mu \mathrm{m}$-filtered seawater for ca. $24 \mathrm{~h}$ to prevent starvation and to adapt to the experimental temperature $\left(16^{\circ} \mathrm{C}\right)$. All experiments were conducted during a 2 wk period in July 2002.

Eurytemora affinis and Acartia bifilosa were incubated (1) with a cell suspension of Rhodomonas salina (as non-toxic control treatment); (2) with $0.2 \mu \mathrm{m}$ filtered seawater (as starvation treatment); and (3) with a cell suspension of Prymnesium parvum (as toxic food treatments). $P$. parvum was grown in 3 different growth media: (1) phosphorus-limited (Pry -P; $80 \mu \mathrm{M}$ $\mathrm{NO}_{3}$ and $\left.1 \mu \mathrm{M} \mathrm{PO}\right)_{4}$; (2) nitrogen-limited (Pry $-\mathrm{N}_{\text {; }}$ $16 \mu \mathrm{M} \mathrm{NO} \mathrm{NO}_{3}$ and $4 \mu \mathrm{M} \mathrm{PO}_{4}$ ); and (3) NP-balanced medium (Pry +NP; $58 \mu \mathrm{M} \mathrm{NO}_{3}$ and $3.6 \mu \mathrm{M} \mathrm{PO}_{4}$ ) (see Uronen et al. 2005). In the experiments with E. affinis, both the control-food and toxic-food treatments had 5 target prey cell concentrations: 2000, 5000, 10000 , 50000 and 100000 cells $\mathrm{ml}^{-1}$, whereas in the experiments with $A$. bifilosa, the median cell concentration (10 000 cells $\mathrm{ml}^{-1}$ ) was used (Table 1). The cell suspensions were prepared prior to the incubations by diluting the stock cultures with fresh $\mathrm{f} / 20$ medium with the adjusted N:P ratios. Biomass ratios between the copepods and their food were adjusted by increasing the number of copepod individuals per bottle with increasing cell concentration of $P$. parvum and $R$. salina, in order to enable the measurement of grazing at high food concentrations (Table 1). Experiments were carried out with 10 experimental units per treatment (6 treatments with copepods +4 control treatments). Each experiment lasted for $3 \mathrm{~d}$, consisting of 3 subsequent $24 \mathrm{~h}$ incubations with the same copepods.

The experiments were carried out in $130 \mathrm{ml}$ glass bottles, which were filled completely avoiding air bubbles and placed in a plankton wheel in a thermostated water bath (rotating at a speed of $1 \mathrm{rpm}$, temperature $16^{\circ} \mathrm{C}$, dim light). After every $24 \mathrm{~h}$ incubation period, the contents of each bottle were poured into a large Petri dish, the condition of the copepods was checked, and actively swimming copepods were picked into a fresh food suspension. From the 'old' cell suspension, faecal pellets and the eggs of Acartia bifilosa were collected onto a $50 \mu \mathrm{m}$ net, and a $100 \mathrm{ml}$ subsample was fixed with $4 \%$ acidic Lugol's solution for phytoplankton counts. The rest of the suspension was used for the measurement of haemolytic activity, which was done from 3 replicate samples and 3 grazing controls after the first $24 \mathrm{~h}$ incubation period.

Cell concentrations of Rhodomonas salina or Prymnesium parvum in incubation bottles were analyzed in the beginning and at the end of each $24 \mathrm{~h}$ incubation period with an electronic particle counter (Elzone, Particle Data). Grazing (filtration and ingestion rates) was calculated according to Frost (1972) for each $24 \mathrm{~h}$ period from the disappearance of the food cells from the experimental bottles with copepods, in comparison to the control bottles without copepods. In the $P$. parvum treatments, most of the grazing values were negative or not significantly different from zero. These negative findings most probably were due to higher algal growth in the presence of copepods, which enhanced nutrient regeneration, compared with the controls without copepods. The values from the highest cell concentration levels (100000 cells ml-1) were omitted, because the grazer:food carbon ratio turned out to be too low $(<10 \%)$ to give a reliable grazing signal. Similarly, the replicates where $>30 \%$ of the copepods died during the incubation were omitted from the analysis.

Faecal pellets were counted from 3 to 6 replicates using a stereo microscope (Zeiss Stemi SV 11). Faecal pellet volume was estimated from 3 replicates in each treatment by measuring the length and width of ca. 30 pellets. Their carbon content was calculated using the

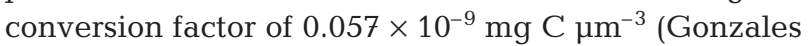
\& Smetacek 1994).

Table 1. Concentrations of target prey cells $\left(\times 10^{3}\right.$ cells $\left.\mathrm{ml}^{-1}\right)$, initial cells $\left(\times 10^{3}\right.$ cells $\left.\mathrm{ml}^{-1}\right)$ and carbon $\left(\mu \mathrm{g} \mathrm{Cl}^{-1}\right.$; mean $\left.\pm \mathrm{SE}\right)$, as well as number of copepods (Zpl) and percentage of copepod carbon $(\% \mathrm{C})$ of phytoplankton carbon, in Eurytemora affinis and Acartia bifilosa experiments

\begin{tabular}{|lrccrr|}
\hline Treatment & $\begin{array}{c}\text { Target } \\
\text { density }\end{array}$ & $\begin{array}{c}\text { Real } \\
\text { density }\end{array}$ & $\begin{array}{c}\text { Carbon } \\
\text { content }\end{array}$ & Zpl & $\%$ C \\
\hline Eurytemora affinis & & & \\
Rho 1 & 2 & $3.5 \pm 0.4$ & $150 \pm 17$ & 2 & 40 \\
Rho 2 & 5 & $6.3 \pm 0.6$ & $265 \pm 25$ & 3 & 30 \\
Rho 3 & 10 & $11.4 \pm 0.7$ & $480 \pm 30$ & 6 & 35 \\
Rho 4 & 50 & $49.2 \pm 1.1$ & $2070 \pm 45$ & 10 & 10 \\
Rho 5 & 100 & $98.9 \pm 1.2$ & $4150 \pm 490$ & 10 & 7 \\
Pry -N1 & 2 & $2.5 \pm 0.2$ & $80 \pm 4$ & 2 & 70 \\
Pry -N2 & 5 & $5.1 \pm 0.9$ & $160 \pm 30$ & 3 & 50 \\
Pry -N3 & 10 & $11.0 \pm 1.4$ & $350 \pm 45$ & 6 & 45 \\
Pry -N4 & 50 & $45.5 \pm 0.9$ & $1455 \pm 30$ & 10 & 20 \\
Pry -N5 & 100 & $91.6 \pm 0.7$ & $2930 \pm 85$ & 10 & 9 \\
Pry -P1 & 2 & $2.6 \pm 0.4$ & $85 \pm 10$ & 2 & 65 \\
Pry -P2 & 5 & $5.1 \pm 0.4$ & $160 \pm 10$ & 3 & 50 \\
Pry -P3 & 10 & $10.8 \pm 0.8$ & $350 \pm 25$ & 6 & 50 \\
Pry -P4 & 50 & $51.4 \pm 1.6$ & $1650 \pm 50$ & 10 & 15 \\
Pry -P5 & 100 & $105.5 \pm 6.0$ & $3370 \pm 190$ & 10 & 8 \\
Pry +NP1 & 2 & $3.0 \pm 0.8$ & $95 \pm 25$ & 2 & 60 \\
Pry +NP2 & 5 & $5.2 \pm 0.4$ & $165 \pm 10$ & 3 & 50 \\
Pry +NP3 & 10 & $9.2 \pm 0.6$ & $300 \pm 20$ & 6 & 55 \\
Pry +NP4 & 50 & $50.4 \pm 0.8$ & $1600 \pm 25$ & 10 & 15 \\
Pry +NP5 & 100 & $104.2 \pm 0.9$ & $3340 \pm 30$ & 10 & 8 \\
Acartia bifilosa & & & & & \\
Rho 3 & 10 & $13.5 \pm 0.5$ & $570 \pm 20$ & 6 & 15 \\
Pry -N3 & 10 & $9.6 \pm 0.2$ & $310 \pm 5$ & 6 & 25 \\
Pry -P3 & 10 & $11.5 \pm 0.4$ & $370 \pm 10$ & 6 & 20 \\
Pry +NP3 & 10 & $10.1 \pm 0.3$ & $3245 \pm 10$ & 6 & 20 \\
& & & & & \\
\hline
\end{tabular}


The eggs produced by the broadcast spawning Acartia bifilosa were counted from 3 to 6 replicate samples using the same stereo microscope after each $24 \mathrm{~h}$ incubation period. To measure the egg production of the egg-carrying Eurytemora affinis, females were incubated in individual vials (in $0.2 \mu \mathrm{m}$-filtered seawater) for $48 \mathrm{~h}$ after the initial $3 \mathrm{~d}$ experiments. The number of eggs and nauplii were then counted and egg production estimated using:

$$
P=N_{\mathrm{e}} /\left(N_{\mathrm{f}} D\right)
$$

where $P=$ egg production (eggs ind. ${ }^{-1} \mathrm{~d}^{-1}$ ), $N_{\mathrm{e}}=$ number of eggs, $N_{\mathrm{f}}=$ number of females and $D=$ temperature-dependent development time of eggs (estimated to be $2.06 \mathrm{~d}$ at $16^{\circ} \mathrm{C}$; Andersen \& Nielsen 1997).

Weight-specific egg production was calculated assuming carbon contents of $3.6 \mu \mathrm{g} \mathrm{C}$ ind..$^{-1}$ for Eurytemora affinis and $1.5 \mu \mathrm{g} \mathrm{C}$ ind. ${ }^{-1}$ for Acartia bifilosa (Koski 1999). The carbon content of eggs (0.04 $\mu \mathrm{g} \mathrm{C}$ $\mathrm{egg}^{-1}$ ) was estimated from an average egg diameter of $82 \mu \mathrm{m}$ (Katajisto et al. 1998) and a carbon content of $0.14 \times 10^{-6} \mu \mathrm{g} \mathrm{C} \mu \mathrm{m}^{-3}$ (Kiørboe \& Sabatini 1995). Gross growth efficiency (GGE, \% $\mathrm{d}^{-1}$ ) of the copepods was calculated from the weight-specific egg production rate divided by their average weight-specific ingestion.

Haemolytic activity. Haemolytic activity of the Prymnesium parvum cultures, as an estimate of their toxicity, was measured daily from the initial cultures (Uronen et al. 2005) and on the first experimental day from all experimental treatments. For the haemolytic activity assay, $10 \mathrm{ml}$ of $P$. parvum suspension was filtered onto GF/C glass-fibre filters, and haemolytic activity of the samples was measured according to the method described in Igarashi et al. (1998), Johansson \& Granéli (1999) and Uronen et al. (2005).

Statistical analyses. Differences in the grazing, survival (percentages arcsine transformed) and egestion of Eurytemora affinis were tested with a 2-way ANOVA, using cell concentration and algal treatment (Rhodomonas salina, Prymnesium parvum -N, - $\mathrm{P}$, + NP) as independent variables. The differences in the egg production of $E$. affinis were tested using a 1-way ANOVA. Grazing, egestion and egg production of Acartia bifilosa were tested with a 2-way ANOVA, using day and algae treatment as independent variables. Survival on Day 3 was tested with a 1-way ANOVA. If conditions for the ANOVA (normality and equality of variances) were not met, a non-parametric Kruskall-Wallis test was used instead. The Holm-Sidak method (2-way ANOVA), Tukey test (ANOVA) or Dunn's method (Kruskal-Wallis ANOVA) were used for all pairwise comparisons. The analyses were performed with SigmaStat for Windows 3.0.1 (SPSS) software.

\section{RESULTS}

Toxicity

At the beginning of the experiments, the cultures of Prymnesium parvum had reached a steady state, and they were toxic independent of the N:P ratio of the culture medium (Uronen et al. 2005). The highest toxicity (haemolytic activity per cell) was measured in the Nand P-depleted cultures, in which the particulate N:P ratios were 12 and 33 (mol:mol), respectively, whereas in the $+\mathrm{NP}$ culture, in which the particulate $\mathrm{N}: \mathrm{P}$ ratio was close to the balanced Redfield ratio (Table 2; Redfield 1958), the toxicity was ca. 20 to $40 \%$ lower. The cell concentration of $P$. parvum varied between $1.5 \times$ $10^{3}(-\mathrm{N})$ and $3.8 \times 10^{3}(+\mathrm{NP})$ cells $\mathrm{ml}^{-1}$ (Table 2 ).

During the grazing experiments, the toxicity of Prymnesium parvum decreased in all treatments, both with and without copepods (Table 3). In the Eurytemora affinis experiments, the decrease was ca. 51 and $44 \%$ with and without animals, respectively, while the corresponding decrease in the Acartia bifilosa experiments was ca. 70 and 58\%. However, differences in the toxicity between the copepod units and the controls were not statistically significant.

\section{Grazing}

The functional response of Eurytemora affinis with Rhodomonas salina was typical: ingestion rate increased with increasing food concentration (2-way ANOVA: $\mathrm{df}_{\text {conc.,total }}=4,53 ; F_{\text {conc. }}=3.7 ; \mathrm{p}=0.01$ ), and filtration rate remained stable or decreased slightly (Fig. 1). In contrast to the treatments with $R$. salina, no statistical differences between the ingestion rates at different Prymnesium parvum $(-\mathrm{N},-\mathrm{P},+\mathrm{NP})$ cell concentrations were found. E. affinis ingested $R$. salina significantly more (from 20 to $240 \%$ of the body carbon $\mathrm{d}^{-1}$ ) compared with $P$. parvum, which was ingested at only $\leq 2.5 \%$ of body carbon $\mathrm{d}^{-1}$ (2-way ANOVA: $\left.\mathrm{df}_{\text {algae,total }}=3,42 ; F_{\text {algae }}=4.6 ; \mathrm{p}=0.01\right)$. At the lowest cell concentration (2000 cells $\mathrm{ml}^{-1}$ ) in both $-\mathrm{N}$ and $+\mathrm{NP}$ treatments, the filtration rate on $P$. parvum was, how-

Table 2. Average $( \pm \mathrm{SE})$ cell concentration $\left(\times 10^{3}\right.$ cells $\left.\mathrm{ml}^{-1}\right)$, cellular N:P ratio (PON:POP, mol:mol) and haemolytic activity (HA) (SnE pg cell ${ }^{-1}$ ) in semi-continuous cultures of Prymnesium parvum in a steady state

\begin{tabular}{|llll|}
\hline & Cell conc. & PON:POP & HA \\
\hline$-\mathrm{N}$ & $148 \pm 11.3$ & $12 \pm 0.9$ & $136 \pm 7.2$ \\
$-\mathrm{P}$ & $308 \pm 5.8$ & $33 \pm 4.4$ & $200 \pm 10.4$ \\
$+\mathrm{NP}$ & $378 \pm 7$ & $16 \pm 1.2$ & $105 \pm 5.4$ \\
\hline
\end{tabular}


Table 3. Haemolytic activity $( \pm \mathrm{SE})\left(\mathrm{SnE}\right.$ pg cell $\left.{ }^{-1}\right)$ in the Eurytemora affinis and Acartia bifilosa grazing experiments with different nutrient treatments $\left(-\mathrm{N}_{1}-\mathrm{P}_{1}+\mathrm{NP}\right)$. Start: initial values; End $_{\text {control }}$ : values after $24 \mathrm{~h}$ incubation without copepods; End $_{\text {copepods: }}$ : with copepods; -: data missing

\begin{tabular}{|lccc|}
\hline & Start & End $_{\text {control }}$ & End $_{\text {copepods }}$ \\
\hline E. affinis & & & \\
$-\mathrm{N}$ & 164 & $126 \pm 19$ & $117 \pm 6.7$ \\
$-\mathrm{P}$ & 158 & $48 \pm 5.6$ & $77 \pm 7.8$ \\
$+\mathrm{NP}$ & 109 & $43 \pm 2$ & $52 \pm 6.7$ \\
A. bifilosa & & & - \\
$-\mathrm{N}$ & 157 & - & $72 \pm 7.2$ \\
$-\mathrm{P}$ & 179 & $67 \pm 3.5$ & $32 \pm 2.3$ \\
$+\mathrm{NP}$ & 73 & $16 \pm 0$ & \\
\hline
\end{tabular}
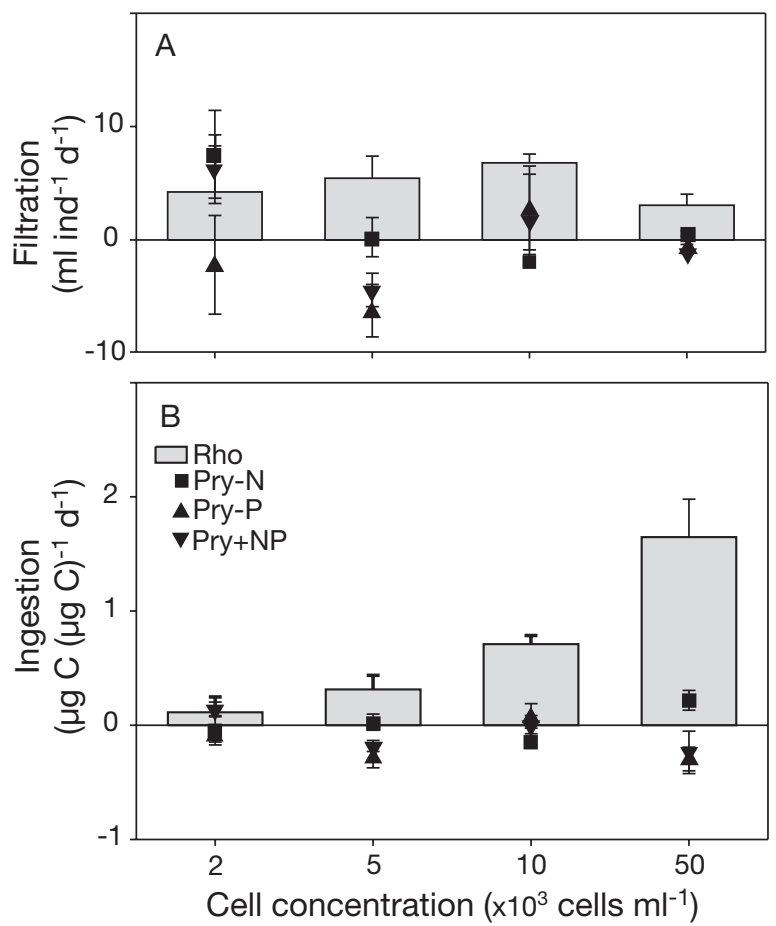

Fig. 1. Average $( \pm \mathrm{SE})(\mathrm{A})$ filtration and (B) weight-specific ingestion of Eurytemora affinis feeding on Rhodomonas salina (Rho) or Prymnesium parvum (Pry -N, $-\mathrm{P},+\mathrm{NP}$ )

ever, slightly higher $\left(-\mathrm{N}, 7.5 \pm 3.8 \mathrm{ml}\right.$ ind. ${ }^{-1} \mathrm{~d}^{-1} ;+\mathrm{NP}$, $6.2 \pm 3 \mathrm{ml}$ ind..$\left.^{-1} \mathrm{~d}^{-1}\right)$ compared to $R$. salina $(4.2 \pm 2 \mathrm{ml}$ ind..$^{-1} \mathrm{~d}^{-1}$; Fig. $1 \mathrm{~A}$ ), indicating that $E$. affinis ingested $P$. parvum cells in small amounts in these treatments (Fig. 1B).

Acartia bifilosa had lower filtration rates on Rhodomonas salina compared with Eurytemora affinis at a cell concentration of $10 \times 10^{3}$ cells ml $^{-1}$ (Fig. 2A). However, because $A$. bifilosa is smaller than $E$. affinis, the ingestion rates (Fig. 2B) were comparable, correspond-
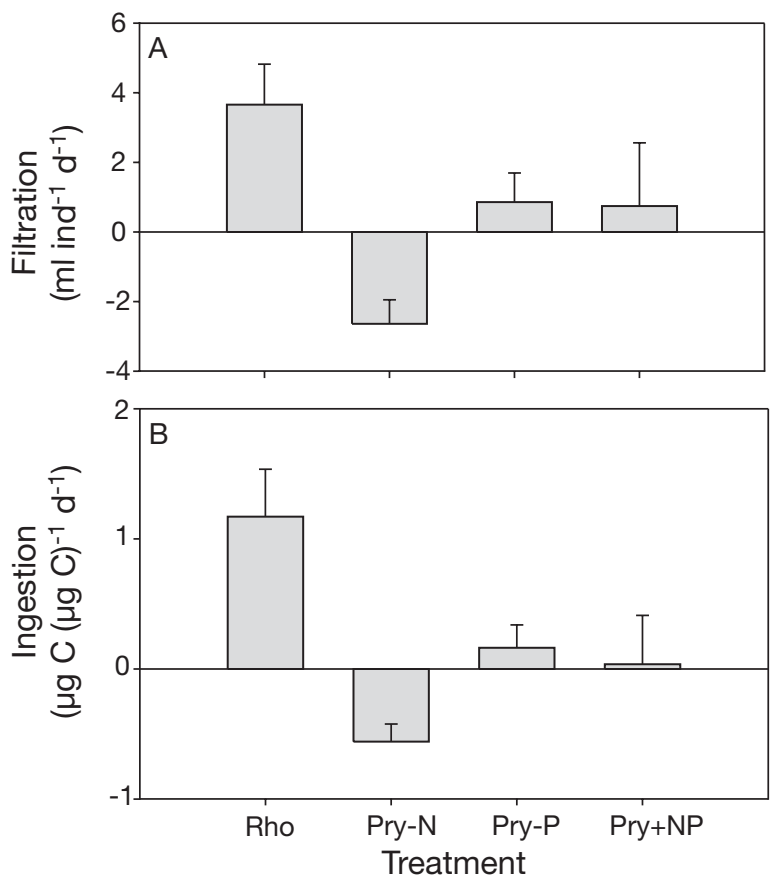

Fig. 2. Average $( \pm \mathrm{SE})$ (A) filtration and (B) weight-specific ingestion of Acartia bifilosa feeding on Rhodomonas salina (Rho) or Prymnesium parvum (Pry $-\mathrm{N},-\mathrm{P},+\mathrm{NP}$ )

ing to ca. $120 \%$ of body carbon $\mathrm{d}^{-1}$. The filtration rates on Prymnesium parvum cells were clearly lower compared with those on $R$. salina, being always less than $20 \%$ of body carbon $\mathrm{d}^{-1}$ (Fig. 2A). Consequently, $P$. parvum treatments differed significantly from $R$. salina treatment during the experiments (2-way ANOVA: $\left.\mathrm{df}_{\text {day,total }}=2,54 ; F=38 ; \mathrm{p} \leq 0.001\right)$.

\section{Egestion}

The production of faecal pellets by Eurytemora affinis reflected its feeding during the experiment. Weight-specific pellet production $\left(\mu \mathrm{g} \mathrm{C}(\mu \mathrm{g} \mathrm{C})^{-1} \mathrm{~d}^{-1}\right)$ was extremely low both in the filtered seawater treatment and when E. affinis was feeding on Prymnesium parvum (corresponding to ca. 0.3 to 0.8 pellets ind. $^{-1}$ $\mathrm{d}^{-1}$ ), irrespective of the cell concentration or the nutrient treatment (Fig. 3). In contrast, the average weightspecific pellet production with the Rhodomonas salina diet was 50- to 200-fold higher, corresponding to 29 pellets ind. ${ }^{-1} \mathrm{~d}^{-1}$ (2-way ANOVA: $\mathrm{df}_{\text {conc.,algae, interact.,total }}=$ $4,3,12,59 ; F_{\text {conc. }}=0.9, F_{\text {algae }}=117.8, F_{\text {interact. }}=0.1 ;$ $\mathrm{p}_{\text {algae }} \leq 0.001 ;$ Fig. 3).

The average weight-specific pellet production of Acartia bifilosa was similarly higher with the Rhodomonas salina diet (corresponding to ca. 15 pellets ind. ${ }^{-1}$ $\mathrm{d}^{-1}$ ), compared with the Prymnesium parvum or fil- 


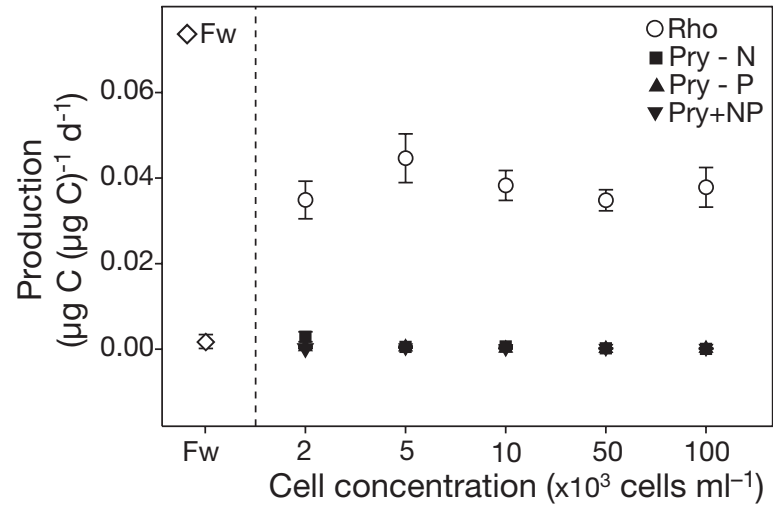

Fig. 3. Average $( \pm \mathrm{SE})$ weight-specific pellet production of Eurytemora affinis in $0.2 \mu \mathrm{m}$-filtered seawater $(\mathrm{Fw})$ and at different concentrations of Rhodomonas salina (Rho) and Prymnesium parvum (Pry $-\mathrm{N},-\mathrm{P},+\mathrm{NP})$

tered seawater treatments $\left(<0.5\right.$ pellets ind. ${ }^{-1} \mathrm{~d}^{-1}$; Fig. 4). The pellet production rates were significantly different during all incubation periods. Weight-specific pellet production varied between days with the $R$. salina diet, but it was always ca. 200-fold compared with the $P$. parvum treatments, in which pellet production was low (2-way ANOVA: $\mathrm{df}_{\text {day,algae,interact.,total }}=$ $2,4,8,88 ; F_{\text {day }}=76, F_{\text {algae }}=744, F_{\text {interact. }}=78 ; \mathrm{p} \leq 0.001$ for all).

\section{Activity and survival}

The individuals of Eurytemora affinis moved actively in the Rhodomonas salina suspension and in the $0.2 \mu \mathrm{m}$-filtered seawater, whereas in the Prymnesium parvum treatments, the copepods were inactive and displayed reduced pipette avoidance. Although average survival percentage of $E$. affinis in the $P$. parvum treatments on Day 3 was slightly lower (26 to $58 \%$ for $-\mathrm{N}, 46$ to $63 \%$ for $-\mathrm{P}, 31$ to $66 \%$ for $+\mathrm{NP}$ ) compared with that in the R. salina treatments (43 to $86 \%$ ) and in the $0.2 \mu \mathrm{m}$-filtered seawater $(60 \%$; Fig. 5), the differences were not statistically significant (2-way ANOVA: $\mathrm{df}_{\text {Conc., algae, interact., total }}=4,4,16,143 ; F_{\text {conc. }}=0.5, F_{\text {algae }}=$ 1.0, $F_{\text {interact. }}=0.7$ ). Fairly high copepod mortality was found once in the first incubation period in the $R$. salina treatment, but due to an unknown cause. The visually observed end condition of copepods incubated with $P$. parvum was, however, noticeably worse than the actual survival rates indicated (Fig. 5).

Accordingly, the individuals of Acartia bifilosa moved more actively in the Rhodomonas salina suspension and in the $0.2 \mu \mathrm{m}$-filtered seawater compared with individuals in the Prymnesium parvum treatments. In spite of that, only minor differences in sur-

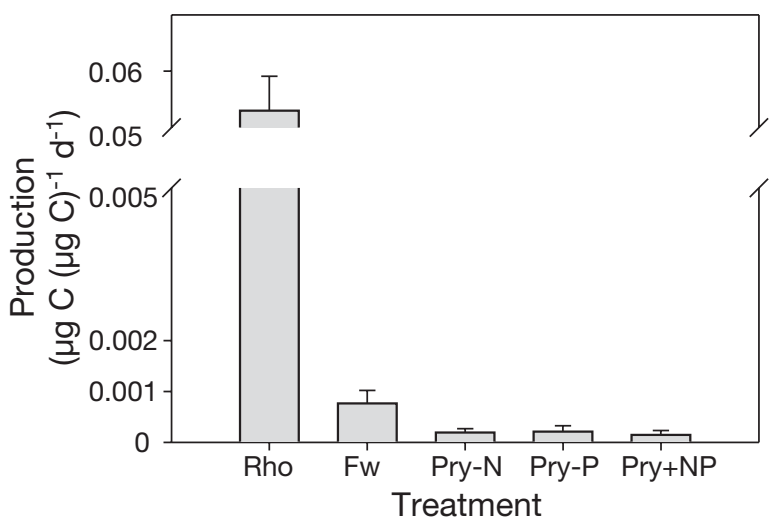

Fig. 4. Average $( \pm \mathrm{SE})$ weight-specific pellet production of Acartia bifilosa in $0.2 \mu \mathrm{m}$-filtered seawater (Fw) or with Rhodomonas salina (Rho) and Prymnesium parvum (Pry $-\mathrm{N}$, $-\mathrm{P},+\mathrm{NP})$ diets

vival between the treatments could be found. While $100 \pm 0 \mathrm{SE} \%(\mathrm{n}=6)$ of the individuals in the $R$. salina treatments were alive at the end of the experiment, the corresponding percentages $( \pm \mathrm{SE})$ in the $0.2 \mu \mathrm{m}$ filtered seawater and in the $P$. parvum $(-\mathrm{N},-\mathrm{P},+\mathrm{NP})$ treatments were $89 \pm 3.9(\mathrm{n}=6), 84 \pm 5.5(\mathrm{n}=6), 72 \pm$ $15(n=6)$ and $71 \pm 15 \%(n=6)$, respectively (Fig. 5). These differences were not statistically significant (ANOVA on ranks, $\mathrm{p}=0.1$ ).

\section{Reproduction}

The average egg production rate of Eurytemora affinis was highest in the Rhodomonas salina treatments $\left(3.2 \pm 1.2\right.$ eggs ind. $\left..^{-1} \mathrm{~d}^{-1}, \mathrm{n}=17\right)$; in the Prymnesium parvum $-\mathrm{P}(0.6 \pm 0.45 ; \mathrm{n}=14)$ and $+\mathrm{NP}(1.9 \pm 0.9 ; \mathrm{n}=$ 16) treatments and the $0.2 \mu \mathrm{m}$-filtered seawater treatment $(0 \pm 0 ; \mathrm{n}=2)$, the egg production was significantly

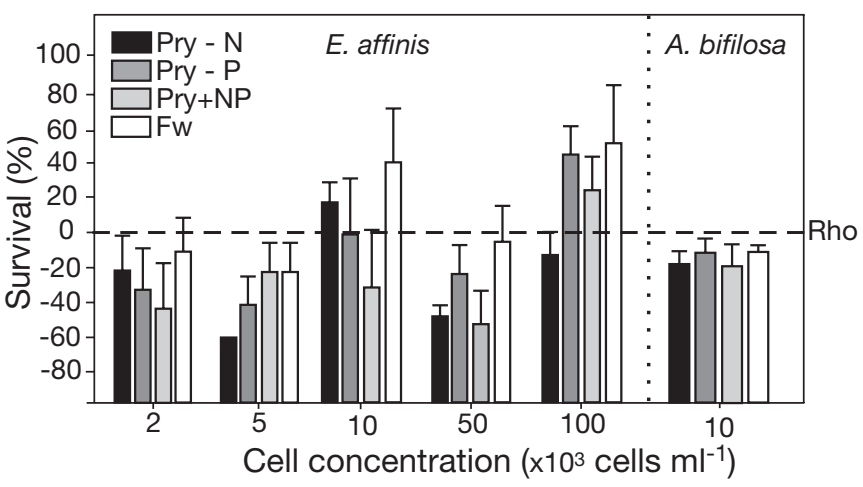

Fig. 5. Survival ( \pm SE) of Eurytemora affinis and Acartia bifilosa on Day 3 (\% of survival with the Rhodomonas salina (Rho) diet [zero reference line]) in the Prymnesium parvum (Pry -N, $-\mathrm{P}$, $+\mathrm{NP}$ ) and $0.2 \mu \mathrm{m}$-filtered seawater $(\mathrm{Fw})$ treatments 
lower (ANOVA on ranks, $\mathrm{p}<0.001$, performed with pooled cell concentrations). The copepods in the $-\mathrm{N}$ treatments were severely impaired, and thus egg production could not be measured. Correspondingly, the GGEs were higher with the $R$. salina diet $\left(21.5 \% \mathrm{~d}^{-1}\right)$ compared with the different $P$. parvum diets (1.3 to $19 \% \mathrm{~d}^{-1}$ ).

Likewise, Acartia bifilosa produced higher amounts of eggs with the Rhodomonas salina diet compared with the Prymnesium parvum $(-\mathrm{N},-\mathrm{P},+\mathrm{NP})$ and $0.2 \mu \mathrm{m}$-filtered seawater treatments (2-way ANOVA: $\left.\mathrm{df}_{\text {algae,total }}=4,89 ; F_{\text {algae }}=39 ; \mathrm{p} \leq 0.001\right)$. Average egg production rate was $2.9 \pm 0.6$ with the $R$. salina diet, $0.5 \pm 0.1$ with $0.2 \mu \mathrm{m}$-filtered seawater, and $0.9 \pm 0.2$, $0.6 \pm 0.2$ and $0.6 \pm 0.2$ with $P$. parvum $-\mathrm{N},-\mathrm{P}$, and $+\mathrm{NP}$ diets, respectively. GGEs of $A$. bifilosa were higher with the $R$. salina diet $\left(15.3 \% \mathrm{~d}^{-1}\right)$ compared to the $P$. parvum treatments $\left(3.3 \% \mathrm{~d}^{-1}\right.$ in the $-\mathrm{P}$, and $1.5 \% \mathrm{~d}^{-1}$ in the $+\mathrm{NP}$ ). The highest egg production rates (3.8 to 8.4 eggs ind. ${ }^{-1} \mathrm{~d}^{-1}$ ) were detected on the last incubation day with the $R$. salina diet (2-way ANOVA: df day,total $=$ 2,$\left.89 ; F_{\text {day }}=19.2 ; \mathrm{p} \leq 0.001\right)$. In contrast, the egg production rate remained low or even decreased in the $P$. parvum and $0.2 \mu \mathrm{m}$-filtered seawater treatments.

\section{DISCUSSION}

\section{Activity and survival of copepods}

Eurytemora affinis and Acartia bifilosa were active in the Rhodomonas salina treatments and in the $0.2 \mu \mathrm{m}$-filtered seawater. In addition, E. affinis showed obvious functional response in weight-specific ingestion to the concentration of non-toxic food (Fig. 1B). In contrast, in the cell suspensions of Prymnesium parvum ingestion was low or undetectable at all cell concentrations. Copepods were also severely impaired and reacted slowly to mechanical disturbance (some of the individuals were only vibrating slightly). This finding is consistent with video observations of E. affinis by Koski et al. (1999b).

Haemolytic activity assays indicated that all our Prymnesium parvum cultures used in the experiments were toxic. In the balanced nutrient cultures (+NP) the toxicity was, however, ca. $45 \%$ lower compared with the N- and P-limited ones (Uronen et al. 2005). The observed degrees of $P$. parvum toxicity were manifested systematically in the survival, activity and feeding of the copepods, suggesting that even the least toxic cultures were potent enough to deter the grazers.

Because the copepods were active in the $0.2 \mu \mathrm{m}$ filtered seawater during the experiments, their inactivity was most likely caused by the toxin or other deleterious effects by Prymnesium parvum, rather than due to starvation. For example, Meldahl \& Fonnum (1995) studied how purified toxin extracted from $P$. patelliferum affects rat brain synaptosomes. They found that the algal extract increased the permeability to $\mathrm{Na}^{+}, \mathrm{Ca}^{+}$and $\mathrm{K}^{+}$in the synaptosomal membrane and that membrane depolarization and inhibition of the net uptake of L-glutamate also occurred. This kind of general effect on the cell membranes can possibly be seen as paralyzing symptoms in the copepods. Despite the obvious influence on the condition and performance of the copepods, the toxicity was not fully reflected in their mortality, probably partly due to the reasonably short duration of the experiments.

There are only a few studies on acute toxicity of Prymnesium parvum on copepods. In one of the earliest investigations, Valkanov (1964) demonstrated that $P$. parvum has toxic effects on a large number of organisms. However, the copepods (Cyclops sp. and Calanipeda sp.) did not show any signs of acute mortality or inactivity, even after $3 \mathrm{~d}$ exposure to $P$. parvum $(1.1 \times$ $10^{8}$ cells $\mathrm{l}^{-1}$ ). In accordance with this study, Nejstgaard et al. (1995) found no mortality or visible effect on the swimming activity of Calanus finmarchicus and Acartia clausi after $2 \mathrm{~d}$ exposure to $P$. patelliferum in concentrations of $10^{9}$ cells $\mathrm{l}^{-1}$. In contrast, Koski et al. (1999b) found elevated mortality when copepods were fed with $P$. patelliferum (cell concentration range 13 to

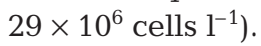

These controversial results of mortality and incapacitation of copepods suggest that responses to Prymnesium parvum toxins can be species specific. Copepod species that are intolerant to the toxins of $P$. parvum may thus become easily inactive in a bloom situation, which further enhances the bloom development. It has been shown, however, that the toxicity of $P$. parvum varies significantly due to culturing conditions (Johansson \& Granéli 1999, Uronen et al. 2005). If one strain can modify its toxicity, it is far from certain that the results obtained with different strains are directly comparable. Therefore, it is obvious that verification and quantification of the prey culture toxicity at the time of the experiments is necessary in order to make a comparative evaluation of the tolerance of different grazers.

\section{Grazing and egestion}

In our experiments both copepod species fed effectively on Rhodomonas salina and mostly avoided Prymnesium parvum. Even though the average ingestion rate on $P$. parvum usually did not differ significantly from zero, the filtration rates indicated that Eurytemora affinis occasionally ingested small amounts of $P$. parvum. This was most pronounced at 
the lowest $P$. parvum concentration (2000 cells $\left.\mathrm{ml}^{-1}\right)$. However, the feeding of $E$. affinis on $P$. parvum was too low to allow observation of any functional responses to increasing cell concentration. Acartia bifilosa responded to $P$. parvum with low or negative ingestion rates, and no relationships between the nutrient treatment and the ingestion rates were found.

The results of this study are in accordance with Nejstgaard et al. (1995), who found that Calanus finmarchicus had generally very low feeding rates on $P$. patelliferum (daily food to body carbon ratio always less than $1 \%$ ). However, Koski et al. (1999b) found that ingestion rates of Eurytemora affinis on P. patelliferum (0.3 to $\left.0.6 \mu \mathrm{g} \mathrm{C}(\mu \mathrm{g} \mathrm{C})^{-1} \mathrm{~d}^{-1}\right)$ were higher than those in our results. In their study, the copepods were acclimated to the experimental food for $5 \mathrm{~d}$, and P. patelliferum cultures were not limited by essential nutrients, which may have affected their toxicity. The copepods in our study were inactive and clearly incapacitated in the presence of Prymnesium parvum during the $3 \mathrm{~d}$ experimental period, which makes it very improbable that they would have started to feed on $P$. parvum after a longer exposure.

Even if it has been suggested that top-down control by zooplankton grazers may prevent bloom formation or shorten the duration of blooms (Buskey et al. 1997, Turner \& Tester 1997, and references therein), our results, as well as previous studies with the common copepods of the North Sea and the Baltic Sea, show that copepods avoid feeding on Prymnesium parvum or ingest it only in small amounts (Nejstgaard et al. 1995, Nejstgaard \& Solberg 1996, this study). The low faecal pellet production of Eurytemora affinis and Acartia bifilosa supports this view.

\section{Reproduction}

Eurytemora affinis and Acartia bifilosa showed reduced fecundity on a diet of Prymnesium parvum compared with Rhodomonas salina. In the non-toxic food treatments, the egg production of $E$. affinis and $A$. bifilosa was well within the range ( 3 to 7 eggs ind. ${ }^{-1}$ $\mathrm{d}^{-1}$, maximum 8 eggs ind. ${ }^{-1} \mathrm{~d}^{-1}$ ) reported by Koski et al. (1999a, 2002), who used another good-quality algae, Brachiomonas submarina.

The difference between non-toxic and toxic food was clearly seen in our experiments with Acartia bifilosa: egg production increased constantly during the incubations with Rhodomonas salina, whereas the Prymnesium parvum diet caused constantly low egg production rate. As egg production of Eurytemora affinis was calculated on the basis of $48 \mathrm{~h}$ incubation after the $3 \mathrm{~d}$ experiment, no corresponding trend could be found.
The reduced fecundity was probably caused by low feeding rates on Prymnesium parvum together with the inactivation of copepods. This is consistent with earlier studies that showed decreased egg production because copepods avoided feeding on prymnesiophytes, e.g. P. patelliferum (Nejstgaard \& Solberg 1996) or Chrysochromulina polylepis (Nielsen et al. 1990). In situations where copepods avoid feeding on algae because of taste, toxicity (Nielsen et al. 1990, Nejstgaard \& Solberg 1996, Dutz 1998), shape/size (Infante \& Abella 1985, Berggreen et al. 1988) or low nutritional value (Jønasdøttir 1994, Schmidt \& Jónasdóttir 1997, and references therein), it is beneficial to allocate energy reserves to survival rather than reproduction. In our experiments, the lower GGEs found with $P$. parvum diet support this hypothesis.

\section{CONCLUSIONS}

In our experiments, Prymnesium parvum had immediate negative effects on copepods. In all nutrient treatments $(-\mathrm{P},-\mathrm{N},+\mathrm{NP})$ and at all cell concentrations, both Eurytemora affinis and Acartia bifilosa became inactive and mostly avoided feeding on the algae. Due to low feeding rates, exceptionally low pellet production and egg production rates were observed. Despite the obvious influence on the condition and performance of the copepods, the toxicity of $P$. parvum was not fully reflected in their mortality, probably due to the reasonably short duration of the experiments. Copepod grazing could not control the growth of $P$. parvum. Inactivation of copepods, followed by low feeding rates, can instead promote development of $P$. parvum blooms.

Acknowledgements. We thank the Tvärminne Zoological Station (University of Helsinki) for providing the laboratory facilities and the FATE team for the congenial atmosphere during the experiments. We especially thank S. Lehtinen for helping with algae dilutions and J. Hagström and L. T. Phuong for toxin analyses. We also thank 4 anonymous reviewers for their helpful comments, which significantly improved the manuscript. This work was funded by the European commission through the FATE project 'Transfer and Fate of Harmful Algal Bloom (HAB) Toxins in European Marine Waters' (EVK3-CT2001-00055) as part of the EC-EUROHAB cluster. M.K. and S.S. were funded by the Academy of Finland. Culturing facilities at Tvärminne Zoological Station were partly funded by the Academy of Finland.

\section{LITERATURE CITED}

Andersen CM, Nielsen TG (1997) Hatching rate of the eggcarrying estuarine copepod Eurytemora affinis. Mar Ecol Prog Ser 160:283-289

Aure J, Rey F (1992) Oceanographic conditions in the Sands- 
fjord system, western Norway, after a bloom of the toxic Prymnesiophyte Prymnesium parvum Carter in August 1990. Sarsia 76:247-254

Barreiro A, Guisande C, Maneiro I, Lien TP and 5 others (2005) Relative importance of the different negative effects of the toxic haptophyte Prymnesium parvum on Rhodomonas salina and Brachionus plicatilis. Aquat Microb Ecol 38:259-267

Berggreen U, Hansen B, Kiørboe T (1988) Food size spectra, ingestion and growth of the copepod Acartia tonsa during development: implications for determination of copepod production. Mar Biol 99:341-352

Buskey EJ, Montagna PA, Amos AF, Whitledge TE (1997) Disruption of grazer populations as a contributing factor to the initiation of the Texas brown tide algal bloom. Limnol Oceanogr 42:1215-1222

Carlsson P, Granéli E, Finenko G, Maestrini SY (1995) Copepod grazing on a phytoplankton community containing the toxic dinoflagellate Dinophysis acuminata. J Plankton Res 17:1925-1938

Dussart BH, Defaye D (2001) Introduction to the copepoda. In: Dumont HJF (ed) Guides to the identification of the microinvertebrates of the continental waters of the world, Vol 16. Backhuys Publishers, Leiden, p 4-11

Dutz J (1998) Repression of fecundity in the neritic copepod Acartia clausi exposed to the toxic dinoflagellate Alexandrium lusitanicum: relationship between feeding and egg production. Mar Ecol Prog Ser 175:97-107

Edvardsen B, Paasche E (1998) Bloom dynamics and physiology of Prymnesium and Chrysochromulina. In: Anderson DM, Cembella AD, Hallegraeff GM (eds) Physiological ecology of harmful algal blooms. NATO ASI Series, Vol G 41. Springer-Verlag, Berlin, p 193-208

Fistarol GO, Legrand C, Granéli E (2003) Allelopathic effect of Prymnesium parvum on a natural plankton community. Mar Ecol Prog Ser 225:115-125

Frost BW (1972) Effects of size and concentration of food particles on the feeding behaviour of the marine planktonic copepod Calanus pacificus. Limnol Oceanogr 17:805-815

Gonzales HE, Smetacek V (1994) The possible role of the cyclopoid copepod Oithona in retarding vertical flux of zooplankton faecal material. Mar Ecol Prog Ser 113: 233-246

Granéli E, Johansson N (2003) Effects of the toxic haptophyte Prymnesium parvum on the survival and feeding of a ciliate: the influence of different nutrient conditions. Mar Ecol Prog Ser 254:49-56

Guillard RR, Ryther JH (1962) Studies of marine planktonic diatoms. Cyclotella nana Hustedt, and Detonula confervacea (Cleve) Gran. Can J Microbiol 8:229-239

Guisande C, Frangópulos M, Carotenuto Y, Maneiro I, Riveiro I, Vergara AR (2002) Fate of paralytic shellfish poisoning toxins ingested by the copepod Acartia clausi. Mar Ecol Prog Ser 240:105-115

Guo M, Harrison PJ, Taylor FJR (1996) Fish kills related to Prymnesium parvum N. Carter (Haptophyta) in the People's Republic of China. J Appl Phycol 8:111-117

Hallegraeff GM (1992) Harmful algal blooms in the Australian region. Mar Pollut Bull 25:186-190

Igarashi T, Aritake S, Yasumoto T (1998) Biological activities of Prymnesin-2 isolated from a red tide alga Prymnesium parvum. Nat Toxins 6:35-41

Infante A, Abella SEB (1985) Inhibition of Daphnia by Oscillatoria in Lake Washington. Limnol Oceanogr 30:1046-1052

Johansson N, Granéli E (1999) Influence of different nutrient conditions on cell density, chemical composition and toxicity of Prymnesium parvum (haptophyta) in semi-continu- ous cultures. J Exp Mar Biol Ecol 239:243-258

Jønasdøttir SH (1994) Effects of food quality on the reproductive success of Acartia tonsa and Acartia hudsonica: laboratory observations. Mar Biol 121:67-81

Kaartvedt S, Johnsen TM, Aksnes DL, Lie U (1991) Occurrence of the toxic phytoflagellate Prymnesium parvum and associated fish mortality in Norwegian fjord system. Can J Fish Aquat Sci 48:2316-2323

Katajisto T, Viitasalo M, Koski M (1998) Seasonal occurrence and hatching of calanoid eggs in sediments of the northern Baltic Sea. Mar Ecol Prog Ser 163:133-143

Kiørboe T, Sabatini M (1995) Scaling of fecundity, growth and development in marine planktonic copepods. Mar Ecol Prog Ser 120:285-298

Koski M (1999) Carbon:nitrogen ratios of Baltic Sea copepods - indication of mineral limitation? J Plankton Res 21: 1565-1573

Koski M, Engström J, Viitasalo M (1999a) Reproduction and survival of the calanoid copepod Eurytemora affinis fed with toxic and non-toxic cyanobacteria. Mar Ecol Prog Ser 186:187-197

Koski M, Rosenberg M, Viitasalo M, Tanskanen S, Sjölund U (1999b) Is Prymnesium patelliferum toxic for copepods? Grazing, egg production and egestion of the calanoid copepod Eurytemora affinis in mixtures of 'good' and 'bad' food. ICES J Mar Sci 56:131-139

Koski M, Schmidt K, Engström-Öst J, Viitasalo M, Jónasdóttir SH, Repka S, Sivonen K (2002) Calanoid copepods feed and produce eggs in the presence of toxic cyanobacteria Nodularia spumigena. Limnol Oceanogr 47:878-885

Larsen A (1999) Prymnesium parvum and Prymnesium patelliferum (haptophyta)-one species. Phycologia 38: 541-543

Lindholm T, Virtanen T (1992) A bloom of Prymnesium parvum Carter in a small coastal inlet in Dragsfjärd, southwestern Finland. Environ Toxicol Water Qual 7:165-170

Lindholm T, Öhman P, Kurki-Helasmo K, Kincaid B, Meriluoto J (1999) Toxic algae and fish mortality in a brackishwater lake in Åland, SW Finland. Hydrobiologia 397: 109-120

Meldahl AS, Fonnum F (1995) The effects of purified toxic extract of Prymnesium patelliferum on transport of ions through the plasma membrane of synaptosomes. Toxicon 33:1071-1086

Nejstgaard JC, Solberg PT (1996) Repression of copepod feeding and fecundity by the toxic haptophyte Prymnesium patelliferum. Sarsia 81:339-344

Nejstgaard JC, Båmstedt U, Bagøien E, Solberg PT (1995) Algal constraints on copepod grazing. Growth state, toxicity, cell size, and season as regulating factors. ICES J Mar Sci 52:347-357

Nielsen GT, Kiørboe T, Bjørnsen PK (1990) Effect of Chrysochromulina polylepis subsurface bloom on the planktonic community. Mar Ecol Prog Ser 62:21-35

Niemi Å (1975) Ecology of phytoplankton in the Tvärminne area, SW coast of Finland II. Primary production and environmental conditions in the archipelago and the sea zone. Acta Bot Fenn 105:1-73

Redfield AC (1958) The biological control of chemical factors in the environment. Am Sci 46:205-221

Richardson K (1997) Harmful or exceptional phytoplankton blooms in the marine ecosystem. In: Blaxter J, Southward A (eds) Advances in marine biology, Vol 31. Academic Press, New York, p 302-385

Schmidt K, Jónasdóttir SH (1997) Nutritional quality of two cyanobacteria: how rich is 'poor' food? Mar Ecol Prog Ser 151:1-10 
Shilo M (1971) Toxins of chrysophycae. In: Kadis S, Ciegler A, Ajl SJ (eds) Microbial toxins: a comprehensive treatise, Vol VII. Algal and fungal toxins. Academic Press, New York, p 67-103

Teegarden GJ (1999) Copepod grazing selection and particle discrimination on the basis of PSP toxic content. Mar Ecol Prog Ser 181:163-176

Turner JT, Tester PA (1997) Toxic marine phytoplankton, zooplankton grazers, and pelagic food webs. Limnol Oceanogr 42:1203-1214

Uronen P, Lehtinen S, Legrand C, Kuuppo P, Tamminen T (2005) Haemolytic activity and allelopathy of the hapto-

Editorial responsibility: Howard Browman (Associate Editorin-Chief), Storebø, Norway phyte Prymnesium parvum in nutrient-limited and balanced growth conditions. Mar Ecol Prog Ser 299: $137-148$

Uye S (1996) Introduction of reproductive failure in the planktonic copepod Calanus pacificus by diatoms. Mar Ecol Prog Ser 133:89-97

Uye S, Takamatsu K (1990) Feeding interactions between planktonic copepods and dinoflagellates from Japanese coastal waters. Mar Ecol Prog Ser 59:97-107

Valkanov A (1964) Untersuchungen über Prymnesium parvum Carter und seine toxische Einwirkung auf die Wasserorganismen. Kiel Meeresforsch 20:65-81

Submitted: November 15, 2005; Accepted: May 11, 2006

Proofs received from author(s): November 17, 2006 